KAIROS ELT JOURNAL, Vol. 2, No. 2, August 2018

Copyright $\odot 2018$, ISSN: 2580-4278

\title{
IMPROVING STUDENTS' READING COMPREHENSION BY USING KNOW- WANT-LEARN (KWL) STRATEGY AT SMP DHARMA WANITA MEDAN
}

\author{
Ika Sasmina br Munthe, Rosa Maria Simamora, Jontra Jusat Pangaribuan \\ Catholic University of Saint Thomas
}

\begin{abstract}
This study is aimed at finding out the impacts of the use of Know-Want-Learn strategy in improving the reading comprehension among seventh grade students of SMP Dharma Wanita Medan in the academic year of 2016/2017. The study was action research in two research cycles. In the study, the writer collaborated with the English teachers and the students. The data of this study were qualitative in nature supported by quantitative data. Qualitative data were obtained from the results of classroom observation and collaborators' discussion. Quantitative data were obtained from pre-test and post test results. The instruments for collecting the data were observation, interview, and the pre-test and posttest. The data were in the form of field notes, interview, and the scores of the students' pre-test and posttest. A t-test was used for the analysis of the quantitative data.

The results of the two cycles show that the use of Know-Want-Learn Strategy is effective to improve the students' reading comprehension. It is supported by the qualitative data which show that (1) Know-Want-Learn Strategy can help the teacher to increase the students' comprehension of the text; (2) Know-Want-Learn strategy can help the students to preview the text, assess what they have learned after reading, and attract their interest in reading. The finding is also supported by the quantitative data. The mean of the students' reading comprehension scores improves from 31 in the pre-test to 58 in the post-test. From the results above, it can be concluded that the use of Know-Want-Learn strategy can improve students' reading comprehension.
\end{abstract}

Keywords: reading comprehension, know-want-learn strategy, classroom action research

\section{INTRODUCTION}

English is an introduction spoken language in international event and is used as the medium of information flow on science, technology, and culture as well. As we are in developing country we should try to be able to speak English to make relationship with other country in the world so that we can master the science, technology and culture in the world. So we can face the competition in the global era. By mastering English, it is easier for us to make a good relationship with other countries.

In education context, English has function as a means to communicate in the daily communication to get knowledge, to make interpersonal communication, to share information and to enjoy language lesson in English culture. There are four skills that must be mastered in English. They are speaking, listening, reading and writing. In learning English, students can be a versatile learner by mastering every language skills. One of the important skills that should be mastered by the students is reading.

Reading is one of the basic skills in English which is not word by word but need to be acquired during language course. Reading is one of important parts to getting achievement in English. Therefore, when the students learn to read, they should be able to comprehend the readings text during the process of reading. They are not only expected to read the text or find out meaning of each word within the text. Arthur (2007:3) states," reading is an extraordinary achievement when one considers the number of levels and components that must be mastered". 
KAIROS ELT JOURNAL, Vol. 2, No. 2, August 2018

Copyright $\odot 2018$, ISSN: 2580-4278

The essence of reading is comprehension. Comprehension is the peak of the reading skills and the bases for all reading processes. It is viewed by some researchers as the ultimate objective of the reading process, since they who do not comprehend what they read is considered as if they have not read. Reading comprehension is process of readers combining information from a text and their own prior knowledge to build meaning. Without comprehending the text, it means the readers do not understand the text well and the readers are not able to get the meaning from the text. Doris (2004: 6) states," reading comprehension is a dynamic interactive process of constructing". However, there are five components of reading comprehension that have to be considered. They are: finding factual information, finding main idea, findings supporting idea, finding the meaning of vocabulary, and identifying reference.

Students usually find some difficulties in reading in which influence their achievement in reading. The purpose of teaching reading is to comprehend and react to what is written. However it is not easy for the students to comprehend the text. They should have the ability to comprehend meaning of the text. The ability to comprehend something from reading materials for students who learn a foreign language needs to be improved in order to make them easier in reading process and to give them enough time in developing their ability.

Based on the problem above it is necessary to apply the method or strategies to solve students from reading problem in English in order students can read and understand meaning of every reading passage. Know-Want-Learn (KWL) Strategy is chosen to solve this problem. Ogle (1986:564) Prior knowledge is extremely important in influencing how we interpret what we read and what we learn from. The strategy is designed to be used by a teacher and group of the student working together. It is then easily transferred into a method for students' independent study. This situation inspiration the writer to made a classroom action research, because the writer wants to know how good Know-Want-Learn (KWL) strategy can improve students' reading comprehension. So the researcher makes a classroom action research with the title Improving Students' Reading Comprehension by Using Know-Want-Learn (KWL) at SMP Darma Wanita Medan in Academic 2016/2017.

\section{REVIEW OF LITERATURE Reading}

Reading is an influential process for increasing one's knowledge of language and it enhances understanding of another culture and other ways of thinking. According to Nunan (2003:68) states," reading is a fluent process of readers combining information from a text and their own background knowledge to build meaning". Reading is one of the four language skills that should be master by every student if they want to comprehend the text entirely.

Harmer (1995:215) states that reading is often a prelude to a speaking or writing activity. In the development of the theory of reading comprehension, bottom-up and top-down processing strategies are important for readers.

Grabe (2002:9) investigated reading for academic purposes and they also provided some guidelines for the English for Learners (EFL) teachers. Their investigation revealed that students read in order to accomplish various purposes. Some students try to obtain only the core concept of the texts so they skim the texts. Occasionally, students establish special information from the written materials by reading.

However, reading sometimes takes place for learning the texts' content and learning materials. Eventually, some students want to integrate information from several texts or numeral books in order to evaluate the information in a critical manner. The aim of reading revealed that it is a way to comprehend the meaning of a text to get information and to enrich students' knowledge and experience.

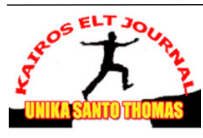


KAIROS ELT JOURNAL, Vol. 2, No. 2, August 2018

Copyright $\odot 2018$, ISSN: 2580-4278

\section{Types of Reading}

Brown (2004: 189) state that there are four types of reading, they are:

1. Perceptive

Perceptive reading task involve attending to the components of larger stretches of discourse: letters, words, punctuation and other graphitic symbols. In this case the learners are expected becoming literate in both of their native speaker or in language that have learned. By doing this task they will get a lot benefits, one of it is they able to write and read.

2. Selective

This category is largely an artifact of assessment formals. In order to ascertain one's reading recognition of lexical, grammatical, of discourse features of language within a very short stretch of language, certain typical tasks are used, picture-cued task, matching, true/false, multiple-choice etc. It means that the learners are expected to understand more detail about the language that they have learned.

3. Interactive

Included among interaction reading types are stretches of language of several paragraph to one page or more in which the reader must in a psycholinguistic sense, interact with the text. That is, reading is a process of negotiating meaning, the reader brings to the text a set of schemata for understanding it and intake is the product of that interaction. So the reader or listener have to make the text into graph or schemata in order to make simple and more easier in understanding it without reading the whole text. Hence the reader can understand immediately by looking the schemata with a little note in the below of it.

4. Extensive

Extensive reading applies to text of more than a page up to and including professional articles, essays, technical reports, short stories and books. The learners must understand the whole text that they have read and the last they can answer the question based on the text.

\section{Reading Comprehension}

Reading comprehension is an active thinking process through which a reader intentionally constructs meaning to form a deeper understanding of concepts and information presented in a text (Westwood, 2008:31). The construction of meaning is done intentionally by connecting, questioning, inferring, and also predicting the ideas in the text to what he already knows. The meaning constructed refers to any combination of word recognition skills, linking of new information to prior knowledge, and application of appropriate strategies. The main purpose of reading text is comprehension of getting meaning of the text. So students will obtain much more information by reading. This is one of the most important factors in modern societies that each individual has to search the information through reading comprehension since much information is available in textbooks, newspapers, magazines, etc that can enrich the readers' knowledge.

From the statements above, it can be concluded that reading comprehension is an active process from a reader constructs the meaning through interpretation and integration with the text to get deeper understanding. Therefore, comprehension is not a passive process but the active one, because in reading comprehension the readers actively interact with the text to construct the meaning. This active interaction includes reading material, interpreting meaning and activating the prior knowledge.

\section{Levels of Reading Comprehension}

The difference of level education makes the difference of level comprehension. By knowing the level of comprehension of students, it can tell us how far the students understand reading material. Burns (1984:177), there are four levels of reading comprehension. There are 
KAIROS ELT JOURNAL, Vol. 2, No. 2, August 2018

Copyright $\odot 2018$, ISSN: 2580-4278

Literal Comprehension, Interpretative Comprehension, Critical Comprehension and Creative Comprehension.

1) Literal Comprehension

Literal comprehension involves the acquiring information that was directly stated in the text. The basic of literal comprehension was recognizing main idea, detailed cause effect, and sequence. It also perquisites for the higher - level understanding. Mastering the basic of literal comprehension can be done through understanding of vocabulary, sentence, meaning, and paragraph meaning.

2) Interpretative Comprehension

Interpretative comprehension involves reading between the lines or making inference. It is the ability of the readers to extract the ideas and the information that is not directly stated in the textbook material, using prior or background knowledge. Within this level, readers may make generalizations, determine cause and effect, identify motives, find relationship, predict endings, and make comparison.

3) Critical Comprehension

Critical comprehension involves evaluating written material, comparing the material and drawing conclusions about the accurately, appropriateness and timeless. Critical comprehension refers to the ability to make judgment about ideas and information a writer offers. The critic readers will measure the information from one sources with the other sources based on the standards apply after they can draw the conclusion.

4) Creative Comprehension

Creative comprehension includes creating new ideas from what was learned based on their experience of life and their opinion on issues relevant to the text. It requires readers to think as they read, just as critical reading, and it requires them to use their imaginations.

\section{Teaching Reading Comprehension}

Teaching is an activity in which the teacher guides and facilitates learning, gives a chance for the learners to learn, and sets the condition for learning (Brown, 2000:7). Guidance is done by leading the students to do activities in the effort of getting knowledge. The teacher can help the students in gaining the knowledge by giving tasks. By giving these tasks, the teacher lets the students study by themselves. To make the teaching and learning process run well, the teacher needs to set a good situation for the students to learn. In setting a good condition, the teacher must consider a classroom method or technique that is used as this can influence the way she or he manages the class.

Based on the definition above, teaching reading comprehension is a guidance that is done by the teacher to make learners reach their reading comprehension on the text using a certain technique. The teacher can lead the learners to understand a text by using some strategies on reading comprehension.

\section{Principles in Teaching Reading Comprehension}

In the teaching of reading, the teacher cannot directly just teach reading to the students by giving texts and asks them to understand it. There are some principles which have to be considered by the teacher. As it is proposed by Nunan (2003:74-77), there are eight principles in teaching reading. They are described as follows:

1. Exploit the reader's background knowledge.

Background knowledge includes all of the experiences that the reader brings to a text: life experiences, educational experiences, knowledge of how texts can be organized rhetorically, knowledge how one's first language works, knowledge of how the second language works and cultural background knowledge. Reading comprehension can 
KAIROS ELT JOURNAL, Vol. 2, No. 2, August 2018

Copyright $\odot 2018$, ISSN: 2580-4278

significantly enhanced if background knowledge can be activated by setting goals, asking question, making prediction, teaching text structure and so on.

2. Build a strong vocabulary base.

Recent research emphasized the importance of vocabulary to successful reading. Basic vocabulary should be explicitly taught and second language readers should be taught to use context to effectively guess the meaning of less frequent vocabulary.

3. Teaching for comprehension.

Monitoring comprehension is essential to successful reading. Part of that monitoring process includes verifying that the prediction being made are correct and checking that the reader is making the necessary adjustments when meaning is not obtained

4. Work on increasing reading rate.

One focus here is to teach readers to reduce their dependence on a dictionary. Skills such as scanning, skimming, predicting and identifying main ideas get students to approach reading in different ways. Reader should spend more time analyzing and synthesizing the content of the reading and not focusing on moving through the passage one word at a time. Part of the joy of reading is being able to pick up a book and comprehend it without having to struggle through the task of reading.

5. Teaching reading strategies.

Strategies are the tools for active, self-directed involvement that is necessary for developing communicative ability. Strategies are not a single event, but rather a creative sequence of events that learners actively use. A good technique to sensitize students to the strategies they use is to get them to verbalize (talk about) their thought processes as they read. Readers can listen to the verbal report of another reader who has just read the same material and it is often revealing to hear what other readers have done to get meaning from a passage.

6. Encourage reader to transform strategies in to skills.

An important distinction can be made between strategies and skills Strategies can be defined as conscious actions that learners take to achieve desire goals or objective, while a skill is a strategy that has become automatic. This characterization underscores the active role that readers play in strategies reading. As learners consciously learn practice specific reading strategies, the strategies move from conscious to unconscious from reading strategy to skill.

7. Build assessment and evaluation into your teaching.

Assessing growth and development in reading skills from both a formal and informal perspective requires time and training.

8. Strive for continuous improvement as a reading teacher.

The quality of the individual teacher is integral to success of second/foreign language readers. Reading teachers need to be passionate about their work. They should view themselves as facilitator, helping each reader discover what work best.

\section{Know-Want -Learn (KWL)}

The K-W-L procedure was created by Ogle (1986). It is based on beliefs in the importance of interactive learning and activating prior knowledge before reading influenced the formation of the K-W-L procedure.

Ogle, 2008:114 states," Know-Want-Learn (KWL) is an instructional reading technique that is used to activate students' background knowledge, assist students in setting purposes for reading, and help students to monitor reading comprehension by using graphic organizer". In this definition, four important concepts of Know-Want-Learn (KWL) strategy are used.

Firstly, Know-Want-Learn (KWL) is an instructional reading strategy to aid the teaching of reading. It uses graphic organizer namely KWL chart to help the students record their thinking process before, during, and after reading. Secondly, Know-Want-Learn (KWL)

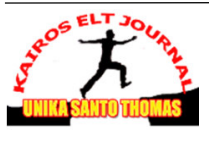


KAIROS ELT JOURNAL, Vol. 2, No. 2, August 2018

Copyright $\odot 2018$, ISSN: 2580-4278

strategy is designed to activate students' background knowledge. By using Know-Want Learn (KWL) strategy, the teacher can help the students recall the information stored in their mind which is related to the topic. Thirdly, Know-Want-Learn (KWL) strategy can assist students in setting purposes for reading. By the use of Know-Want-Learn technique, the teacher can encourage the students to determine why they are reading a specific text. Fourthly, KnowWant-Learn technique helps the students to monitor their own comprehension. Here, the readers can reject or confirm the information stored in their mind with the information they find in the text.

Know-Want-Learn (KWL) consists of three basic stages (Burke, 2005:16). They are K stage, W stage, and L stage.

1. K stage: What I know, students access their background knowledge to the text by listing what they already know about a specific topic.

2. W stage: What I want to know, students determine what they want to know by making questions related to the topic.

3. L stage: What I learn. From the definition, Know-Want-Learn (KWL) strategy can be concluded as a technique which has well-organized steps to be followed by the students. The technique combines the use of reading strategies in the effort to improve reading comprehension.

\section{The Characteristics of Know-Want-Learn (KWL) Strategy}

Know-Want-Learn (KWL) strategy has characteristics that are different from other instructional reading techniques. Below, four characteristics of Know-Want Learn (KWL) are presented.

\section{Using charts}

In the implementation of Know-Want-Learn (KWL) technique, the use of chart is important. The chart used in this technique is known as KWL chart. KWL chart consists of three columns. They are What I Know (K) column, What I want to Know (W) column, and What I learn (L) column. The chart presents a before-during-after strategy that must be completed by the students during the thinking-reading process. The first two sections of the chart are to be filled out prior to the lesson while the last column is to be filled out after the lesson. Know-Want-Learn (KWL) chart helps students to be active thinkers while they read, gives them specific things to look for, and get them reflect on what they have learned. It can be used as a short introduction to a lesson to stimulate prior knowledge and assist the teacher's instruction during the teaching and learning process (Ogle cited in Ros \& Vaughn, 2002:179).

\section{Involving three basic stages}

Know-Want-Learn (KWL) consists of three basic stages (Ros \& Vaughn, 2002: 179). They are $\mathrm{K}$ stage, $\mathrm{W}$ stage, and L stage, in the $\mathrm{K}$ stage: What I know, students access their background knowledge to the text by listing what they already know about a specific topic. Then in the W stage: What I want to know, students determine what they want to know by making questions related to the topic, and finally recall what they learn in the L stage: What I learn. Below is the illustration of the use of KWL chart.

\section{Combining the use of strategies}

Know Want Learn (KWL) strategy involves a variety of strategies to help students make meaning from a text. There are at least three strategies used. They are activating prior knowledge, setting purpose of reading, and monitoring and assessing comprehension (Ros \& Vaughn, 2002:178).

\section{Using interactive processing}

The use of Know-Want-Learn (KWL) strategy can assist the teacher in teaching reading using an interactive model of reading (Ros \& Vaughn, 2002:180). An interactive reading

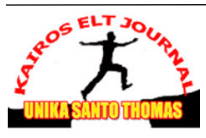


KAIROS ELT JOURNAL, Vol. 2, No. 2, August 2018

Copyright $\odot 2018$, ISSN: 2580-4278

model is a reading model that recognizes the interaction of bottom-up and top-down processes simultaneously throughout the reading process (Brown, 2001:299). An interactive model emphasizes the role of prior knowledge or pre-existing knowledge in providing the readers with implicit information in the text. In the implementation of Know-Want-Learn (KWL) strategy, activating the students' prior knowledge is the most important stage.

In this topic the writer will be use charts. The writer uses charts because charts very simple and easy to us

\begin{tabular}{|l|l|l|}
\hline Know & Want & Learn \\
\hline & & \\
\hline & & \\
\hline & & \\
\hline & & \\
\hline
\end{tabular}

Figure 1. Example of KWL Chart

The Purpose of Know-Want-Learn (KWL) Strategy

There are some purposes of K-W-L technique namely:

1. Elicits students' prior knowledge of the topic of the text

2. Sets a purpose for reading

3. Help students to monitor their comprehension

4. Constructs meaning from what they read

5. Allows the students to assess their comprehension of the text

6. Provides an opportunity for students to expand ideas beyond the text.

\section{How to Use the K-W-L Strategy}

The procedure of using K-W-L strategy is described as the following:

1. Choose one of the reading texts.

2. Create a KWL chart. The teachers create a chart on whiteboard on an overhead transparency. In addition, the students should create chart on which to record information.

3. Ask the students to brainstorm words, terms, or phrases they associate with a topic. The teacher and the students record these associations in the K column of their charts. This is done until students run out of ideas.

4. Ask students what they want to find out or to learn about the topic. The teacher and student record these questions in the $\mathrm{W}$ column of their charts. This is done until students run out of ideas for question. If students respond with statement, turn them into question before recording them in the $\mathrm{W}$ column.

5. Have students read the text and fill out the L column on their chart. Students should look for the answers to the questions in their $\mathrm{W}$ column while they are reading. Students can fill out their L column either during or after reading.

\section{RESEARCH METHOD}

In this study the writer will use classroom action research. Carr and Kemmis in Tran Thi Thu Hien (2009:98) stated that classroom action research is a form of self-reflective enquiry undertaken by participants in social situations in order to improve the rationality and justice of their own practices, their understanding of these practices and the situations in which the practices are carried out.

In this research, observation is done two times, before experiment and after experiment. Observation before the treatment is intended to get information about their reading by interviewing the students and the teacher. After the treatment, another observation is also given

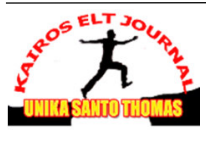


KAIROS ELT JOURNAL, Vol. 2, No. 2, August 2018

Copyright $\odot 2018$, ISSN: 2580-4278

to students and the teacher to get information about the improvement students' reading comprehension by using Know-Want-Learn strategy. The writer takes one group as sample and it is given pre-test and post-test. Pre-test will be administered before the treatment to assess the students' prior knowledge on reading comprehension and the post-test will be administered to measure treatment effects. The aim of these test is to find out the improvement of Know-WantLearn strategy on students' reading comprehension.

\section{DATA ANALYSIS}

The data of this research was collected from the seventh grade students of SMP Dharma Wanita Medan in academic year 2016/2017. In order to obtain reliable data for this research, as stated in Chapter III there were some research instruments administered to the subject under the study. Consequently, there were two raw data gathered for the present study which consisted of pre-test, post-test.

In this study, the data were collected could be distinguished into quantitative and qualitative data. The quantitative data were shown by the students' scores which were collected by the administration of pre-test and post-tests. The pre-test was administered to measure the problems that the students faced in reading comprehension skill. Furthermore, the post-test was administered at the end of each session. The qualitative findings were obtained from interview carried out after cycle II was completed. It showed the response of the subjects under study towards the implementation of KWL strategy in improving reading comprehension.

\section{The Qualitative Data}

The qualitative data consists of the field notes, observation, and interview. They are described as follows:

\section{Field Notes}

\section{a. Meeting 1}

Meeting 1 was held on Friday, $16^{\text {th }}$ September 20016 starting at $10.15-10.55$, in this meeting the writer just given the pretest. Before start lesson, the students and teacher prayed together. The writer greeted the students and introduced herself and directly the writer gave the pretest to the students, when they were doing the test they were also cheating with their friend and they are said that the test was difficult.

b. Meeting 2 (cycle 1)

Meeting 2 was held on Thursday, $22^{\text {th }}$ September 2016, starting at 10.15.00-11.30. The writer greeted the students, then checked attendance list. The writer asked the students by asking if they have still remembered the lesson yesterday. The students remembered the lesson about descriptive text and the writer said 'good job dear'. After that the writer and students sang a song to open the lesson. In this meeting the writer gave a text about place with the title "My Classroom", the writer asked the student what they know about the picture, what they want to know. After that they gave their opinion the writer asked them to create their opinion in column $\mathrm{K}$, after that create what they want to know in column W. After they finished reading the text, they created what they have learned in column L. At the end lesson the writer gave them quiz.

c. Meeting 3 (cycle 1)

Meeting 3 was held on Friday, 23 $3^{\text {th }}$ September 2016 starting at10.15-11.40, greet students and checked the attendance list. Like the previous meetings, the writer asked the students to sit in a group that has been determined before. After that the writer distributed a text and picture about place with the title "Tania's House" to discuss, after which the writer asked all that they know about the picture and ask them to fill the column K, W, and L. After all

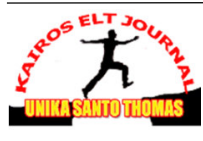


filled, the writer asked students to make a summary from all the columns. And at the end of the lesson the writer asked the students to do the task that have been given.

d. Meeting 4 (cycle 1)

Meeting 4 was held on Thursday $29^{\text {th }}$ September 2016 starting at 10.15-11.30, greet students and checking the attendance list, like previous meetings, the writer asked students to sit with a group that has been determined beforehand. After that the writer distributed a text and picture about thing with the title "Doraemon" for them to discuss, after which the author asks all that they know about the picture and asked students to fill the column $\mathrm{K}, \mathrm{W}$, and L. After all filled, the writer asked them to make a summary of all the columns. And at the end of the lesson the writer asked students to do the task that have been given.

e. Meeting 5 (cycle 2)

Meeting 5 was held on Friday, $30^{\text {th }}$ September 2016 starting at 10.15-11.40, greet students and checking the attendance list, like previous meetings, the writer asked students to sit with a group that has been determined beforehand. After that the writer distributed a text and picture about thing with the title " $m y$ doll" for them to discuss, after which the writer asked all that they know about the picture and ask students to fill the column $\mathrm{K}, \mathrm{W}$, and $\mathrm{L}$. After all filled, the writer asked students to make a summary of all the columns. And at the end of the lesson the writer asked students to do the task that have been given.

f. Meeting 6 (cycle 2)

Meeting 6 was held on Thursday $06^{\text {th }}$ October 2016 starting at 10.15-11.30,, greet students and checking the attendance list, like previous meetings, the writer asked students to sit in a group that has been determined beforehand. After that the writer distributed a text and picture about animals with the title "My Unique Pets" to discuss, after which the writer asked all that they know about the picture and asked students to fill the column $\mathrm{K}, \mathrm{W}$, and L. After all filled, the writer asked students to make a summary of all the columns. And at the end of the lesson the writer asked the students to do the task that have been given.

g. Meeting 7 (cycle 2)

Meeting 7 was held on Friday, $07^{\text {th }}$ October 2016 starting at 10.15-11.40,, greet students and checking the attendance list, like previous meetings, the writer asked the students to sit in a group that has been determined beforehand. After that the writer distributed a text and picture about animals with the title "My Timmy" to discuss, after which the writer asked all that they know about the picture and asked the students to fill the column K, W, and L. After all filled, the writer asked them to make a summary of all the columns. The end of the lesson the writer asked the students to do the task that have been given.

h. Meeting 8

Meeting 8 was held on Thursday $13^{\text {th }}$ October 2016 starting at $10.15-10.55$ in this meeting the writer just give questions to the students for get score of posttest, they did their task individually and the condition of the class quiet.

\section{Interview}

Interview sheet

(Wednesday, September $14^{\text {th }} 2016$ )

W: The writer

$\mathrm{T}$ : The teacher ( Venty Syahmita Ginting)

W: Good morning mam

T: Good morning

$\mathrm{W}$ : Mam, may I ask you some questions related to learning process in the class VIII A?

T: Yes of course

W: How do you think the learning- teaching process in English subject at class VII?

T: I think they are quite well.

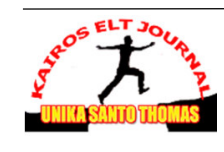


KAIROS ELT JOURNAL, Vol. 2, No. 2, August 2018

Copyright $\odot 2018$, ISSN: 2580-4278

W: How about reading Mam?

T: Some students learn how to read and comprehend what they read quite well, but there are many students who have difficulty in learning how to read and comprehend what they have read.

$\mathrm{W}$ : What are the problems that students faced in reading Mam?

T: The problems are fluency, vocabulary and comprehension. Most students still have difficulties finding factual information, finding main idea, findings supporting idea, finding the meaning of vocabulary,

W: Thank you Mam for your time.

T: You are welcome.

\section{Observation}

Table 1. Observation Sheet Cycle 1

\begin{tabular}{|l|l|l|l|}
\hline No & Description & Yes & No \\
\hline 1 & The teacher comes to the class on time & $\sqrt{ }$ & \\
\hline 2 & The teacher greets the student & $\sqrt{ }$ & \\
\hline 3 & The teacher does the warming up to inform the material & $\sqrt{ }$ & \\
\hline 4 & The teacher reviews the material last meeting & $\sqrt{ }$ & \\
\hline 5 & The teacher informed the objective of the lesson & $\sqrt{ }$ & \\
\hline 6 & The teacher explains the material & $\sqrt{ }$ & \\
\hline 7 & The teacher distributes the descriptive text & $\sqrt{ }$ & \\
\hline 8 & The teacher uses the learning KWL strategy in teaching & $\sqrt{ }$ & \\
\hline 9 & The teacher motivates the students & $\sqrt{ }$ & \\
\hline 10 & The teacher gives formative test & $\sqrt{ }$ & \\
\hline 11 & The teacher concludes the lesson & $\sqrt{ }$ & \\
\hline 12 & The teacher leaves the class on time & $\sqrt{ }$ & \\
\hline 13 & The students listen to the teacher's explanation & & $\sqrt{ }$ \\
\hline 14 & The students participate during the learning process & & $\sqrt{ }$ \\
\hline 15 & The students work in group & $\sqrt{ }$ & \\
\hline 16 & The students do not feel ashamed for asking to the teacher & $\sqrt{ }$ & \\
\hline 17 & The students are active in learning & & $\sqrt{ }$ \\
\hline 18 & The students do the formative test & $\sqrt{ }$ & \\
\hline 19 & The students showed good attitude toward the teaching & & $\sqrt{ }$ \\
\hline 20 & The classroom is clean & $\sqrt{ }$ & \\
\hline 21 & The classroom is noisy & $\sqrt{ }$ & \\
\hline 22 & The classroom is comfortable & $\sqrt{ }$ \\
\hline
\end{tabular}

Table 1 shows that the students were not active and not good attitude in teaching in learning process, they also felt shy for asking the teacher when they faced the difficulty in comprehending text. This situation of the class also was a little noisy during the teaching learning process.

Table 2. Observation Sheet Cycle II

\begin{tabular}{|l|l|l|l|}
\hline No & Description & Yes & No \\
\hline 1 & The teacher comes to the class on time & $\sqrt{ }$ & \\
\hline
\end{tabular}

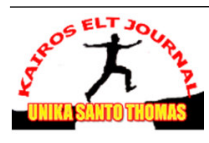


KAIROS ELT JOURNAL, Vol. 2, No. 2, August 2018

Copyright $\odot 2018$, ISSN: 2580-4278

\begin{tabular}{|l|l|l|l|l|}
2 & The teacher greets the student & $\sqrt{ }$ & \\
\hline 3 & The teacher does the warming up to inform the material & $\sqrt{ }$ & \\
\hline 4 & The teacher reviews the material last meeting & $\sqrt{ }$ & \\
\hline 5 & The teacher informed the objective of the lesson & $\sqrt{ }$ & \\
\hline 6 & The teacher explains the material & $\sqrt{ }$ & \\
\hline 7 & The teacher distributes the descriptive text & $\sqrt{ }$ & \\
\hline 8 & The teacher uses the learning cell technique in teaching & $\sqrt{ }$ & \\
\hline 9 & The teacher motivates the students & $\sqrt{ }$ & \\
\hline 10 & The teacher gives formative test & $\sqrt{ }$ & \\
\hline 11 & The teacher concludes the lesson & $\sqrt{ }$ & \\
\hline 12 & The teacher leaves the class on time & $\sqrt{ }$ & \\
\hline 13 & The students listen to the teacher's explanation & $\sqrt{ }$ & \\
\hline 14 & The students participate during the learning process & $\sqrt{ }$ & \\
\hline 15 & The students work in group & $\sqrt{ }$ & \\
\hline 16 & The students do not feel ashamed for asking to the teacher & $\sqrt{ }$ & \\
\hline 17 & The students are active in learning & $\sqrt{ }$ & \\
\hline 18 & The students do the formative test & $\sqrt{ }$ & \\
\hline 19 & The students showed good attitude toward the teaching & $\sqrt{ }$ & \\
\hline 20 & The classroom is clean & $\sqrt{ }$ & \\
\hline 21 & The classroom is noisy & & $\sqrt{ }$ \\
\hline 22 & The classroom is comfortable & $\sqrt{ }$ & \\
\hline
\end{tabular}

Table 2. shows that the students were more actively and not ashamed for asking during the teaching learning process. This situation of the class also was more conducive for teaching learning process. So, it could be concluded that there was an improvement of the students' attitude, students' participation, and the situation the situation of the class in teaching learning process after using Know-Want-Learn (KWL) strategy at the seventh grade of SMP Dharma Wanita Medan.

\section{The Quantitative Data} follows:

Quantitative data consist of the score pre-test and post-test. They are formulated as

Table 3. pre-test rank

\begin{tabular}{|l|l|l|}
\hline No & Category & Students'score \\
\hline 1 & The highest score & 50 \\
\hline 2 & The lowest score & 15 \\
\hline 3 & The average score & 31 \\
\hline
\end{tabular}

Table 3, shows that, the average score of pretest was 31 . There was 1 students got 50 as the highest score and 3 students got 15 as the lowest score. After calculating the pre-test score, the writer calculated the categories of the students' reading comprehension. As the following table:

Table 4. The data frequency of students' score pre-test

\begin{tabular}{|l|l|l|l|l|}
\hline No & Students' score & Category & Students & Percentage(\%) \\
\hline 1 & $90-100$ & Very good & 0 & $0 \%$ \\
\hline
\end{tabular}

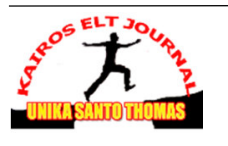


KAIROS ELT JOURNAL, Vol. 2, No. 2, August 2018

Copyright $\odot 2018$, ISSN: 2580-4278

\begin{tabular}{|l|l|l|l|l|}
\hline 2 & $70-89$ & Good & 0 & $0 \%$ \\
\hline 3 & $50-69$ & Fair & 1 & $3,1 \%$ \\
\hline 4 & $30-49$ & Poor & 19 & $59,3 \%$ \\
\hline 5 & $0-29$ & Very poor & 12 & $37,5 \%$ \\
\hline
\end{tabular}

Table 4. shows that, there was 1 student who got fair category $(3,1 \%)$ and 19 students were in poor category $(59,3 \%)$. Besides that, there were 12 students in very poor category of reading comprehension $(37,5 \%)$. So, it could be concluded that students' reading comprehension very low at the seventh grade of SMP Dharma Wanita Medan.

Table 5. cycle 1 rank

\begin{tabular}{|l|l|l|}
\hline No & Category & Students'score \\
\hline 1 & The highest score & 75 \\
\hline 2 & The lowest score & 0 \\
\hline 3 & The average score & 43 \\
\hline
\end{tabular}

Table 5, shows that there were average score of pretest was 43 . There were 2 students got 75 as the highest score and 2 students got 0 as the lowest score. After calculating cycle 1, the writer calculated the categories of students' reading comprehension. As the following table:

Table 6. The data frequency of students' score cycle 1

\begin{tabular}{|l|l|l|l|l|}
\hline No & Interval score & Category & Students & Percentage(\%) \\
\hline 1 & $90-100$ & Very good & 0 & $0 \%$ \\
\hline 2 & $70-89$ & Good & 3 & $9,3 \%$ \\
\hline 3 & $50-69$ & Fair & 15 & $47 \%$ \\
\hline 4 & $30-49$ & Poor & 9 & $39,1 \%$ \\
\hline 5 & $0-29$ & Very poor & 5 & $15,6 \%$ \\
\hline
\end{tabular}

Table 6 shows that, there were 3 students who got good category $(9,3 \%) 15$ students were in fair category (47\%). Besides, 9 students in poor category $(39,1 \%)$ and there were 5 students $(15,6 \%)$ students in very poor category. So, it could be concluded that students' reading comprehension improved after using Know-Want-Learn strategy at the seventh grade of SMP Dharma Wanita Medan.

Table 7. cycle 2 rank

\begin{tabular}{|l|l|l|}
\hline No & Category & Students'score \\
\hline 1 & The highest score & 70 \\
\hline 2 & The lowest score & 20 \\
\hline 3 & The average score & 52 \\
\hline
\end{tabular}

Table 7, shows that there were average score of pretest was 52 . There were 5 students got 70 as the highest score and 2 students got 20 as the lowest score. After calculating cycle 2, the writer calculated the categories of students' reading comprehension. As the following table:

Table 8. The data frequency of students' score cycle 2

\begin{tabular}{|l|l|l|l|l|}
\hline No & Interval Score & Category & Students & Percentage(\%) \\
\hline 1 & $90-100$ & Very good & 0 & $0 \%$ \\
\hline 2 & $70-89$ & Good & 5 & $15,6 \%$ \\
\hline 3 & $50-69$ & Fair & 23 & $71,8 \%$ \\
\hline
\end{tabular}

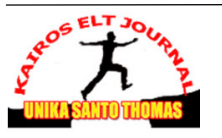


KAIROS ELT JOURNAL, Vol. 2, No. 2, August 2018

Copyright $\odot 2018$, ISSN: 2580-4278

\begin{tabular}{|l|l|l|l|l|}
\hline 4 & $30-49$ & Poor & 7 & $21,8 \%$ \\
\hline 5 & $0-29$ & Very poor & 2 & $6,2 \%$ \\
\hline
\end{tabular}

Table 8 shows that, there were 5 students who got good category $(15,6 \%), 23$ students who got fair category $(71,8 \%), 7$ students who got poor category $(21,8 \%)$ and , 2 students who got very poor category $(6,2 \%)$. So, it could be concluded that students' reading comprehension at the seventh grade of SMP Dharma Wanita Medan still low.

Table 9. Post-test rank

\begin{tabular}{|l|l|l|}
\hline No & Explanation & Students'score \\
\hline 1 & The highest score & 75 \\
\hline 2 & The lowest score & 40 \\
\hline 3 & The average score & 58 \\
\hline
\end{tabular}

Table 9, shows that there were average score of pretest was 58. There were 3 students got 75 as the highest score and 1 student got 40 as the lowest score. After calculating the post test score, the writer calculated the categories of students' reading comprehension. As the following table:

Table 10. The data frequency of students' score post-test

\begin{tabular}{|l|l|l|l|l|}
\hline No & $\begin{array}{l}\text { Interval } \\
\text { Score }\end{array}$ & Category & Students & Percentage(\%) \\
\hline 1 & $90-100$ & Very good & 0 & $0 \%$ \\
\hline 2 & $70-89$ & Good & 12 & $37,5 \%$ \\
\hline 3 & $50-69$ & Fair & 14 & $40,6 \%$ \\
\hline 4 & $30-49$ & Poor & 6 & $43,7 \%$ \\
\hline 5 & $0-29$ & Very poor & 0 & $0 \%$ \\
\hline
\end{tabular}

Table 10, shows that there were 12 students who got good category (37,5\%), 14 students who got fair category $(40,6 \%)$ Besides, 6 students in poor category $(43,7 \%)$. So, it could be concluded that students' reading comprehension improved after using Know-Want-Learn strategy at the seventh grade of SMP Dharma Wanita Medan.

\section{The percentages and the mean score of the test}

The percentage of each test administered to the students in this research after conducting the research at SMP Dharma Wanita Medan, they were described as follows:

Table 11. The percentages of each test

\begin{tabular}{|l|l|l|l|l|l|l|}
\hline No & Interval score & Category & Pretest & Cycle 1 & Cycle 2 & Posttest \\
\hline $\mathbf{1}$ & $90-100$ & Very good & $0 \%$ & $0 \%$ & $0 \%$ & $0 \%$ \\
\hline $\mathbf{2}$ & $70-89$ & Good & $0 \%$ & $9,3 \%$ & $15,6 \%$ & $37,5 \%$ \\
\hline $\mathbf{3}$ & $50-69$ & Fair & $3,1 \%$ & $47 \%$ & $71,8 \%$ & $40,6 \%$ \\
\hline $\mathbf{4}$ & $30-49$ & Poor & $59,3 \%$ & $39,1 \%$ & $21,8 \%$ & $43,7 \%$ \\
\hline $\mathbf{5}$ & $0-29$ & Very poor & $37,5 \%$ & $6,2 \%$ & $6,2 \%$ & $0 \%$ \\
\hline
\end{tabular}

The table 11 shows that there was significant percentage in the students reading comprehension. Based on the percentage score, the students got score $\geq 70$ in pretest was $0 \%$, in cycle 1 was $9,3 \%$, in cycle 2 was $15 \%$, in the posttest was $37,5 \%$. It can be concluded there

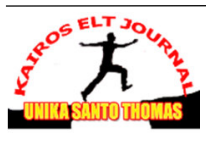


KAIROS ELT JOURNAL, Vol. 2, No. 2, August 2018

Copyright@2018, ISSN: 2580-4278

was an improvement of students' reading comprehension after using Know-Want-Learn (KWL) strategy to the seventh grade students of SMP Dharma Wanita Medan.

The mean score of each test administered to the students could be seen in following table:

Table 12. The mean and percentage score of each test

\begin{tabular}{|l|l|l|}
\hline Test & Mean score & Percentage $\geq \mathbf{7 0}$ \\
\hline Pretest & 31 & $0 \%$ \\
\hline Cycle 1 & 42 & $9,3 \%$ \\
\hline Cycle 2 & 54 & $15,6 \%$ \\
\hline Posttest & 58 & $37,5 \%$ \\
\hline
\end{tabular}

The table 12 shows that there was a significant improvement in the students reading comprehension. In the pretest students' mean score was 31 and the post test was 58 .

\section{Discussion}

The data analysis which established the findings of this study showed that the mean of the pre-test score obtained by the subjects under study in reading comprehension showed out the mean figure of 30.78. This mean figure clearly showed that the student's capability was low. It was really hard to know why the reading comprehension of the students was relatively low since there were so many factors affecting it such the strategies being used was not effective in taught reading comprehension.

The result of the data analysis of the reflection score in cycle I showed the increasing means figure of 42.8. This grand mean figure cycle I showed the obvious improvement of the studentse $^{\text {ee }}$ ability in reading comprehension through KWL strategy. The results of the data analysis of the reflection or post-test scores obtained by the subjects under study for cycle II showed the increasing mean figure of 52.05. Compared with the mean figure of pretest scores, the mean figure obtained by the subjects for each session was convincingly much higher than the pretest mean figure. The difference was 27.34 (30.78-58.12). There was a significant difference of the mean figure suggested than the teaching of reading comprehension by using KWL strategy in cycle II was more effective than cycle I, this was due to the fact that cycle II was a revised version of cycle I, the lesson plan in cycle II were accordingly revised by taking into reflection score in cycle II was much higher than that in cycle I.

\section{CONCLUSIONS}

This study was conducted to help students improve and develop their ability in reading comprehension. The main data required for this study were gathered through administering pretest and posttest to the subjects under study.. The mean score of pretest was 31.00 . The mean figure clearly pointed that the reading comprehension ability of the seventh grade students of SMP Dharma Wanita Medan was considered low, and the grand mean of the posttest was 58.00. The established mean figure for each session was much higher and increased significantly. The findings of this study convincingly revealed that teaching reading by using KWL strategy could effectively improve and increase the low ability in reading comprehension of the seventh grade students of SMP Dharma Wanita Medan.

Those finding above could not be extended and generalized to other groups of students in accordance with the objective class action study, even though they belong to the same school because of the fact that an action class study was mainly undertaken for helping particular groups of students who faced problems in improving reading, therefore the findings were predominantly valid and reliable for seventh grade students of SM Dharma Wanita Medan. 
KAIROS ELT JOURNAL, Vol. 2, No. 2, August 2018

Copyright $\odot 2018$, ISSN: 2580-4278

\section{BIBLIOGRAPHY}

Anderson, Neil. 2003 “What is Reading”? In Nunan, David. Practical English Language Teaching. New York: Mcgraw-hill.

Arthur, C. 2007. Reading Comprehension Strategies, Theories, Interventions and technologies. New York: University of Memphis.

Brown, H. D. 2001. Principle Language and Teaching. New York: Longman.

2004. Language assessment Principles and Classroom Practices. San Francisco: Longman.

Burns, et. al. 1984.Teaching in Today's Elementary School ( $3^{\text {rd }}$ ed). New York: Longman.

Burke, E. 2005. Reading Strategies to Guide Learning. Rapid City: Black Hills Special Service Cooperative (BHSSC).

Hien, T.T.T. 2009. Why is action research suitable for education. Journal of Science, Foreign Languages.

Carr, E. \& Ogle, D. (1987). K-W-L Plus: A Strategy for Comprehension and Summarization. Journal of Reading, 30 (7), 626-631.

Cook, M. 2004. A guide to Curriculum Planning in Reading. Department of Public Instruction. South Webster Street.

Grabe, W and Stoler, F.L. 2002. The Practice of ELT (3rd edition). New York: Longman.

Harmer, J. 1995. The Practice of English Language Teaching. United Kingdom: Longman.

Mikulecky, B.S, and Jeffries, L. 2007. Reading Power. United States of America: Pearson Education.

Nunan. D. 1999. Second Language Teaching and Learning. Article of The Correlation between Reading Comprehension. Boston, U.S.A: Heile Publisher

Ogle, D.M. 1986. K-W-L: A Teaching Model That Develops Active Reading of Expository Text. The Reading Teacher, 39(6), 564-570.

. 2008. Reading Comprehension Strategies for Independent Learners. $\quad$ New York: The Guildford Press

Ros, C. and Vaughn, S. (2002) Strategies for Teaching Students with Learning and Behavior Problems. New York: Rinehart and Winston, Inc.

Snow, C., Chair. (2002). Reading for Understanding (Towards an R\&D Program in Reading Comprehension). Pittsburgh: RAND.

Westwood, P. S. 2008. What Teacher Need to know about Reading and Writing Difficulties. Victoria: Acer Press.

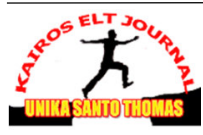

